\title{
偏差係数法を用いた地震による STUDY ON DAMAGE OF BUILDINGS 建築物の中間層崩壊現象の検討 IN INTERMEDIATE STORIES \\ BY EARTHQUAKE USING DEVIATION COEFFICIENT METHOD
}

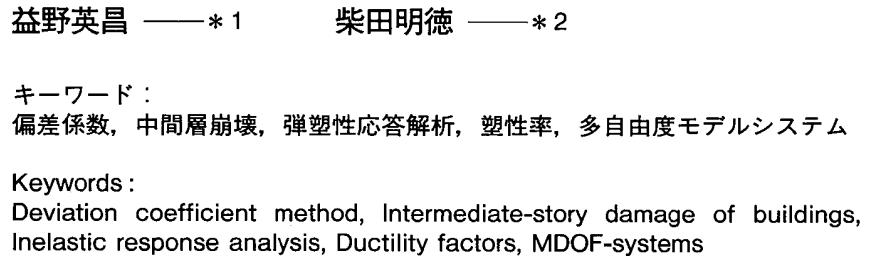

Hidemasa MASUNO — $* 1 \quad$ Akenori SHIBATA — $* 2$

Inelastic response behavior of building models with weak intermediate stories is investigated using deviation coefficient method. The method can explain well the large damage in intermediate stories and the possibility of predicting the response behavior of buildings with irregular strength distribution is shown. Also, the inelastic mode estimation method is applied to interpret the response behavior of intermediate story damage.
1.はじめに

兵庫県南部地震の際に起こった10階建て程度の多くのビル建築にお いて, 中間層崩壊現象 ${ }^{12}{ }^{2)}$ が生じた。この現象に対して, 中間層耐力 低減モデルを用いた弾塑性地震応答解析を行い, 弾性層間変位及び降 伏変位に基づいた偏差係数法による応答性状の检討を行った。さら

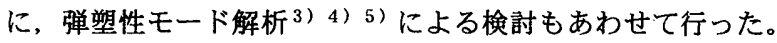

\section{2. 偏差係数法による地震応答性状の検討}

本論では, 梅村・柴田 ${ }^{6 ）}{ }^{7)}$ が示したせん断多質点系の弾塑性応答 性状を推定する偏差係数法を用いて，応答首塑性率が不均一な場合 の弾塑性応答を推定した。ここでは, 中間層の耐力が低く, 中間層 崩壊現象を起こしうる建物モデルを設定した。

\section{1 解析モデルと地震応答解析}

解析モデルは，等質量分布で 1 次モード逆三角形分布となるよう な剛性分布をもつ 6 質点せん断型モデル ${ }^{7)}$ であり，降伏時周期は 0.60 秒とした。また，履歴特性を修正トリリニア型（修正 takeda 型） ${ }^{8)}$ とし，降伏後剛性 $\mathrm{Kp}$ との初期剛性 $\mathrm{K}$ 。との割合 $1 \%$ ，減衰特 性は質量比例型とし，1 次の初期減衰 $\mathrm{h}$ １は $5 \%$ とした。修正トリリ ニアモデルは, 降伏前は原点指向型であり, 降伏後は最大点指向型 として再荷重時の剛性低下を表現したモデルである。ここではひび 割れ点の耐力（荷重） $Q c$ を降伏耐力（降伏荷重） $Q y$ の 1/3 倍（Qc $=Q \mathrm{y} / 3$ ）としている。また, 降伏時剛性 $\mathrm{Ky}$ は初期剛性 $\mathrm{K}$ 。（=ひび 割れ点剛性 $\mathrm{Kc}$ ）の 0.3 倍（ $\mathrm{Ky}=0.3 \mathrm{~K}_{0} ）$ としている。〔図 1〕

耐力分布は $\mathrm{Ai}$ 分布, ベースシャ汒 0.4 とした。この耐力分布のモ デルを原モデル (100\%モデル) として, 中間層である $3 ， 4$ 層の耐 カを低減したモデルを 2 種類設定した。すなわち， $25 \%$ 低減した

1 仙台第二工業高等学校 教諭・博士 (工学) (干983-0042 仙台市宮城野区東宮城野3-1)

*2 東北大学 名誉教授, 東北文化学園大学 教授・工博
低隇モデルA（75\%モデル），50\%低減した低隇モデルB（50\%モデ

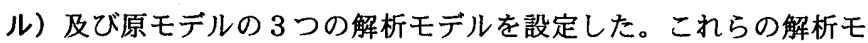
デルに対して，それぞれ地震波 10 波による地震応答記録 30 ケース の計算を行った。使用した入力地震波は，模擬地震波 10 波 ${ }^{8)}$ を使用 した。模擬地震波 10 波の最大加速度の平均值は $405.6 \mathrm{gal}$, 変動係数 は 0.09 である。3つのモデルついて, 模擬地震波 10 波の応答計 算による各層塑性率の平均（以後応答塑性率 $\mu_{\imath}$ ) と変動係数を表 1 に示した。原モデルでは，層塑性率は全首でほぼ 2 であり，低減モ デルでは，3，4層の塑性率が大きく，2，5層の塑性率は小さく なっている。

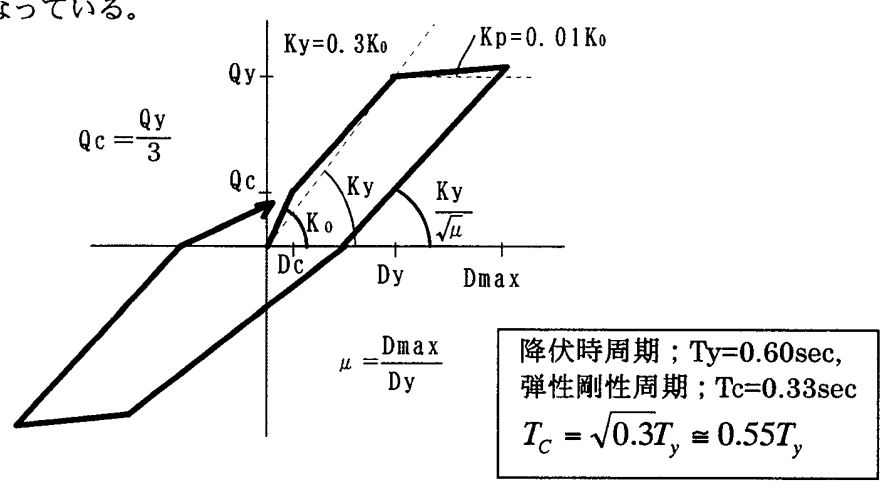

図 1 修正トリリニアモデル

\section{2 偏差係数法}

弾性層間変位及び降伏変位の偏差係数 $\alpha$ （ある層の値と全体の平 均値の比）を用いて, 弾塑性の塑性率 $\bar{\mu}_{i}$ を推定する方法を次に示す。 住を偏差係数法による推定塑性率と呼ぶこととする。

*1 Instructor, Sendai Second Technical High School, Dr. Eng.

*2 Prof. Emeritus, Tohoku Univ., Prof., Tohoku Bunka Gakuen Univ., Dr. Eng. 
弾性層間変位の偏差係数

ここに $\delta_{L i}$; 弾性層間変位, $n$; 層数 $\alpha_{L i}=\frac{\delta_{L i}}{\sum_{j=1}^{n} \delta_{L i}} \cdots[1]$

降伏变位の偏差係数

ここに $\delta_{Y i} ;$ 降伏変位

$$
\alpha_{Y i}=\frac{\delta_{y_{i}}}{\frac{\sum_{j=1}^{n} \delta_{Y_{j}}}{n}}
$$

推定塑性率

ここに $m$; 係数

$$
\bar{\mu}_{i}=\frac{\left(\frac{\alpha_{L_{i}}}{\alpha_{Y_{i}}}\right)^{m} \times \delta_{L_{i}}}{\delta_{Y_{i}}}
$$

推定層間变位

$$
\bar{\delta}_{N i}=\delta_{Y i} \cdot \bar{\mu}=\left(\frac{\alpha_{L i}}{\alpha_{Y i}}\right)^{m} \times \delta_{L i}
$$

推定層間变位和

$$
D_{i}=\sum_{j=1}^{i} \bar{\delta}_{N j} \cdots[5]
$$

\section{3 偏差係数法による塑性率及び応答変位の推定 (1) 塑性率の推定}

3つのモデルに対して，[3] 式により， m の値を 1.0 および 2.0 として求めた推定塑性率 $\overline{\mu_{i}}$ の 10 波平均の值をその変動係数ととも に表 1 に示した。さらに, 弾塑性応答のみかけの塑性率 $\mu_{i}^{\prime}(=$ 弾性 層間変位 $\delta_{L i} /$ 降伏変位 $\delta_{Y i}$, 以後みかけの塑性率) を表 1 に示し た。なお, みかけの塑性率 $\mu_{i}^{\prime}$ は, [3] 式の $\mathrm{m}=0$ の場合である。 また, 因 2 に, グラフ化した 10 波の推定塑性率 $\bar{\mu}_{i}$, みかけの塑性 率 $\mu_{i}^{\prime}$ ，応答塑性率 $\mu_{i}$ を示す。

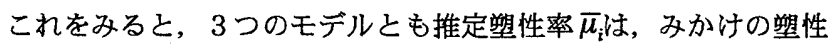

\begin{tabular}{|c|c|c|c|c|c|c|}
\hline \\
\hline ri & 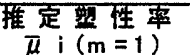 & 痤方 & 5 & $\pi$ & 阵戠 & 及かけの, \\
\hline 6 & $2.23 /(0.18)$ & $\frac{\mu}{2.28}$ & $(0.24)$ & 1.78 & $(0.36)$ & $\frac{\pi}{2.18}$ \\
\hline$\frac{5}{5}$ & $(0.12)$ & 2.36 & $(0.16)$ & 2.40 & $\frac{0.33)}{(0.33)}$ & 2.22 \\
\hline 4 & $(0.08)$ & 2.16 & $(0.10)$ & 2.25 & 6.2 & 2.15 \\
\hline 3 & $(0.06)$ & 2.08 & $(0.09)$ & 2.26 & $(0.22)$ & 2.13 \\
\hline 2 & 2.10 & 2.09 & $(0.10$ & 2.26 & $(0.21)$ & 2.13 \\
\hline & 2.06 & 2.02 & 01 & 2.26 & $(0.17)$ & 2.10 \\
\hline
\end{tabular}
率 $\mu_{i}^{\prime}$ より, 応答塑性率 $\mu_{i}$ に近くなっている。低城モデル $\mathrm{A}, \mathrm{B}$ で

\begin{tabular}{|c|c|c|c|c|c|c|c|}
\hline & & & & A & 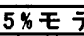 & & \\
\hline 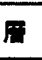 & $\begin{array}{l}\text { 推定 } \\
\bar{\mu} \mathrm{i}\end{array}$ & $\begin{array}{l}\text { 珄率 } \\
\mathrm{m}=1)\end{array}$ & 推定 & $\begin{array}{l}\text { 性率 } \\
n=2 \text { ) }\end{array}$ & 応答 & & 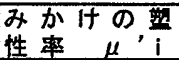 \\
\hline 6 & 2.05 & $(0.18)$ & 1.93 & $(0.24)$ & 1.38 & $(0.15)$ & 2.18 \\
\hline 9 & 2.10 & $(0.12)$ & 2.00 & 0.1 & 0.99 & $(0$. & 2.22 \\
\hline 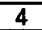 & 3.53 & $(0.08)$ & 4.34 & $(0.1$ & 5.65 & 10 & 2.87 \\
\hline 3 & 3.44 & $(0.06)$ & 4.18 & $(0.09)$ & 5.30 & $(0.27)$ & 2.83 \\
\hline 2 & 1.94 & $(0.07)$ & 1.77 & $(0.10$ & 0.93 & $(0.08)$ & 2.13 \\
\hline & 1.90 & $(0.08)$ & 1.71 & $(0.1$ & 1.13 & $(0.21)$ & 2.10 \\
\hline
\end{tabular}
は, 中間層 $\left(3,4\right.$ 層) の応答塑性率 $\mu_{3}, \mu_{4}$ の突出傾向を, 推定塑

\begin{tabular}{|c|c|c|c|c|c|c|c|}
\hline & & & 盛 & $\operatorname{ll} B$ & $08 \mp$ & & \\
\hline Fin & $\begin{array}{l}\text { 推定 } \\
\bar{\mu} \mathrm{i}\end{array}$ & 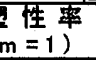 & $\begin{array}{l}\text { 推定 } \\
\bar{\mu} \mathrm{i}\end{array}$ & $n=2)$ & ho & & 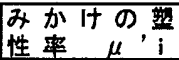 \\
\hline 6 & 1.87 & $(0.18)$ & 1.61 & $(0.24)$ & 0.79 & $(0.18)$ & 2.18 \\
\hline 5 & 1.92 & $(0.12)$ & 1.66 & $(0.16)$ & 0.61 & $(0.08)$ & 2.22 \\
\hline 4 & 7.25 & $(0.08)$ & 12.23 & $(0.10)$ & 9.02 & $(0.13)$ & 4.31 \\
\hline 3 & 7.07 & $(0.06)$ & 11.77 & $(0.09)$ & 8.98 & $(0.15)$ & 4.25 \\
\hline 2 & 1.77 & $(0.07)$ & 1.47 & $(0.10)$ & 0.62 & $(0.11)$ & 2.13 \\
\hline 1 & 1.73 & $(0.08)$ & 1.43 & $(0.13)$ & 0.77 & 10 & 10 \\
\hline
\end{tabular}

\section{表 1 各層の塑性率の平均と变動係数}

性率 $\overline{\mu_{3}}, \overline{\mu_{4}}$ でよく推定している。さらに， 3 層の応答塑性率 $\mu_{3}$ よ り，4層の応答塑性率 $\mu_{4}$ が大きくなる傾向を推定塑性率 $\bar{\mu}_{3}, \bar{\mu}_{4}$ でよ く推定している。しかし， 2 層， 5 層では，推定塑性率 $\bar{\mu}_{i}$ は応答塑 性率 $\mu_{i}$ より，やや大きめになっている。また，中間層（3，4 層） の推定塑性率 $\bar{\mu}_{3}, \bar{\mu}_{4}$ について, $(\mathrm{m}=2)$ による推定值は, 低減モデル A (75\%モデル) では, 応答值より小さくなっているのに対し, 低 減モデル B (50\%モデル) では, 応答值の方が大きくなっている。 $\mathrm{m}$ の妥当な值については, 今後検討の必要がある。

(2) 応答变位の推定

基礎からの応答変位の推定について考察する。

[4]，[5] 式により，mの值を 1.0 および 2.0 として求めた推定層 間変位和 Di の 10 波平均の值を表 2 , 図 3 に示した。この值に対し、 㐫答計算による基礎からの最大変位 $Y_{i \max }$ および $[6]$ 式による最大 層間変位和 $Y_{i \max }^{\prime}$ を比較した。

$$
\begin{aligned}
Y_{i \max }^{\prime} & =\sum_{j=1}^{i} \delta_{N j} \cdots[6] \\
& \text { ここに } \delta_{N i} ; \text { 応答最大層間変位 }
\end{aligned}
$$

\begin{tabular}{|c|c|c|c|c|c|c|c|c|}
\hline & \multicolumn{8}{|c|}{ 原モデル(100\%モデル) } \\
\hline h. & 推定栭 & 复位 & 推定丽 & 変位 & 基硔 & うの晨 & 霞大1 & 槒变位 \\
\hline & 13.41 & $(0.06)$ & 13.39 & 0.06 & 12,34 & $(0,15)$ & $\frac{71}{3.62}$ & $(036)$ \\
\hline 5 & 10.78 & $(0.04)$ & 10.74 & $(0.04)$ & 10.72 & $(0.17)$ & 1752 & $(0.33)$ \\
\hline 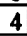 & 8.41 & $(0.04)$ & 8.30 & $(0.04)$ & 8.66 & $(0.18)$ & 9.02 & $(0.21)$ \\
\hline 3 & 6.26 & $(0.06)$ & 6.15 & $(0.06)$ & 6.57 & $(0.19)$ & 3,78 & $(0.22)$ \\
\hline & 4.20 & & 4.11 & $(0.07)$ & 4.46 & & & \\
\hline & 2.10 & $(0.08)$ & 2.05 & $(0.08)$ & .31 & $(0.17)$ & 231 & $(0.17)$ \\
\hline
\end{tabular}

\begin{tabular}{|c|c|c|c|c|c|c|c|c|}
\hline \multicolumn{9}{|c|}{ 低娍モデルA(75\%モデル) } \\
\hline \multirow{2}{*}{6} & \multirow{2}{*}{\multicolumn{2}{|c|}{$\begin{array}{c}\text { 推定两問変位 } \\
\text { 和 } \mathrm{Di}(\mathrm{m}=1)\end{array}$}} & \multirow{2}{*}{\multicolumn{2}{|c|}{ 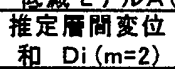 }} & \multirow{2}{*}{\multicolumn{2}{|c|}{ 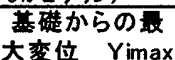 }} & \multirow{2}{*}{\multicolumn{2}{|c|}{$\begin{array}{l}\text { 最大唒間変位 } \\
\text { 和 } Y^{\prime} \text { imax }\end{array}$}} \\
\hline & & & & & & & & \\
\hline & & & & & & & & $(0.15)$ \\
\hline 4 & 003 & 004 & & 0 & 0 & & 100 & \\
\hline & 6.00 & 606 & 9.10 & & $\frac{0.95}{5.1}$ & $\frac{10.11}{10}$ & & $(0.27)$ \\
\hline 2 & 386 & 007 & 348 & & 205 & $\frac{0.404}{(0.13)}$ & & $(0.2$ \\
\hline & 194 & $(0.08)$ & 174 & $\frac{(0.01)}{(0.08)}-(x-1)$ & 1.6 & $\frac{1.101)}{(0.21)}$ & 1.05 & $(0.08)$ \\
\hline
\end{tabular}

最大層間変位和 $Y_{i \max }^{\prime}$ は，位相ずれの分だけ，基礎からの最大変位

\begin{tabular}{|c|c|c|c|c|c|c|c|c|}
\hline \multicolumn{9}{|c|}{ 低減モデルB (50\%モデル) } \\
\hline & \multirow{2}{*}{\multicolumn{2}{|c|}{$\begin{array}{l}\text { 推定間间変位 } \\
\text { 和 } \mathrm{Di}(\mathrm{m}=1)\end{array}$}} & \multirow{2}{*}{\multicolumn{2}{|c|}{$\begin{array}{l}\text { 推定䦵间変位 } \\
\text { 和 } \mathrm{Di}(\mathrm{m}=2)\end{array}$}} & \multirow{2}{*}{\multicolumn{2}{|c|}{ 基礁からの最 }} & \multirow{2}{*}{\multicolumn{2}{|c|}{$\begin{array}{c}\text { 最大届面変位 } \\
\text { 和 } Y^{\prime} \text { imax }\end{array}$}} \\
\hline & & & & & & & & \\
\hline$\underline{6}$ & 14.82 & $(0.05)$ & 18.33 & $(0.05)$ & 10.03 & $(0.09)$ & 11.88 & $(0.18)$ \\
\hline$\underline{5}$ & 12.61 & $(0.04)$ & 16.46 & $(0.04)$ & 9.46 & $(0.09)$ & 10 & $(0.08)$ \\
\hline 4 & 10.61 & $(0.04)$ & 14.74 & $(0.04)$ & 8.96 & $(0.10)$ & 10.31 & $(0.13)$ \\
\hline$\underline{3}$ & 7.01 & $(0.06)$ & 8.67 & $(0.06)$ & 5.16 & $(0.13)$ & 5.83 & (0. \\
\hline 2 & 3.53 & $(0.07)$ & 2.91 & $(0.07)$ & 1.39 & $(0.11)$ & 1.41 & $(0.11)$ \\
\hline & 1.77 & $(0.08)$ & 1.45 & $(0.08)$ & 0.79 & $(0.11)$ & $\underline{9}$ & (0.1) \\
\hline
\end{tabular}
$Y_{i \max }$ より大くなっている。

表 2 各モテルの推定層間变位和 Di と基礎からの最大变位 $Y_{i \max }$.

\begin{tabular}{|c|c|c|c|c|c|c|}
\hline & \multicolumn{6}{|c|}{ 弹栍モデル } \\
\hline Fit & 弾性 & 変位 & 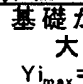 & $\begin{array}{l}5 \text { Б樶 } \\
\sum \delta \text { Li }\end{array}$ & $\begin{array}{c}\text { 最大店 } \\
\text { 和 }\end{array}$ & $\begin{array}{l}\text { 間変 位 } \\
\gamma^{\prime} i_{\max }\end{array}$ \\
\hline 0 & 2.58 & $(0.11)$ & 12.73 & $(0.06)$ & 13.37 & $(0.11)$ \\
\hline 5 & 2.30 & $(0.08)$ & 10.44 & $(0.05)$ & 1089 & $(0.08)$ \\
\hline 4 & 2.1 & & 8.33 & $(0.04)$ & 8.50 & $(0.06)$ \\
\hline 3 & 2. & $(0.04)$ & 6.31 & $(0.04)$ & 6.25 & $(0.04)$ \\
\hline 2 & 2. & & 4.26 & $(0.05)$ & 4.26 & $(0.04)$ \\
\hline & 2.1 & $(0.0$ & 2.15 & $(0.05)$ & 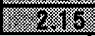 & \\
\hline
\end{tabular}
最大層間变位和 $Y_{i \max }^{\prime}(\mathrm{cm})$

表 3 弾性モデルの基礎からの最大变位 $Y_{i \max }$, 最大層間变位和 $Y_{i \max }^{\prime}$ 
表 2 , 図 3 より, 最大層間変位和 $Y_{i \max }^{\prime}$ と偏差係数法による推定層 間変位和 $\mathrm{Di}(\mathrm{m}=2)$ は, 中間層の層間変位が大きくなる傾向がよ く一致している。しかし，頂部の層間变位和 $\mathrm{D}_{6}$ については，低減 モデル A では, 頂部の最大層間変位和 $Y_{6 \max }^{\prime}$ とほほ一致しているが, 低減モデル B では，その差が大きい。

また, 3 つのモデルとの比較のため, 復元力特性を弾性とした弾 性モデルの基礎からの応答変位 $Y_{i \max }$, 最大層間変位和 $Y_{i \max }^{\prime}$ を表 3 に示した。表 2 と比べると, 原モデルと弾性モデルは, ほぼ同じ 変位となっており，この場合は，ほぼ変位一定則に従っている。（表 2 の『, 表 3 の部分）

\section{3. 弾塑性モード解析による検討}

(1)弾塑性モードの推定

3 つのモデルの模擬地震波 10 波に対する弹塑性地震応答記録 $\{y(t)\}$ 加ら，[7]式による推定 1 次モ一ドベクトル $\left\{{ }_{1} v\right\}$ の 10 波平均
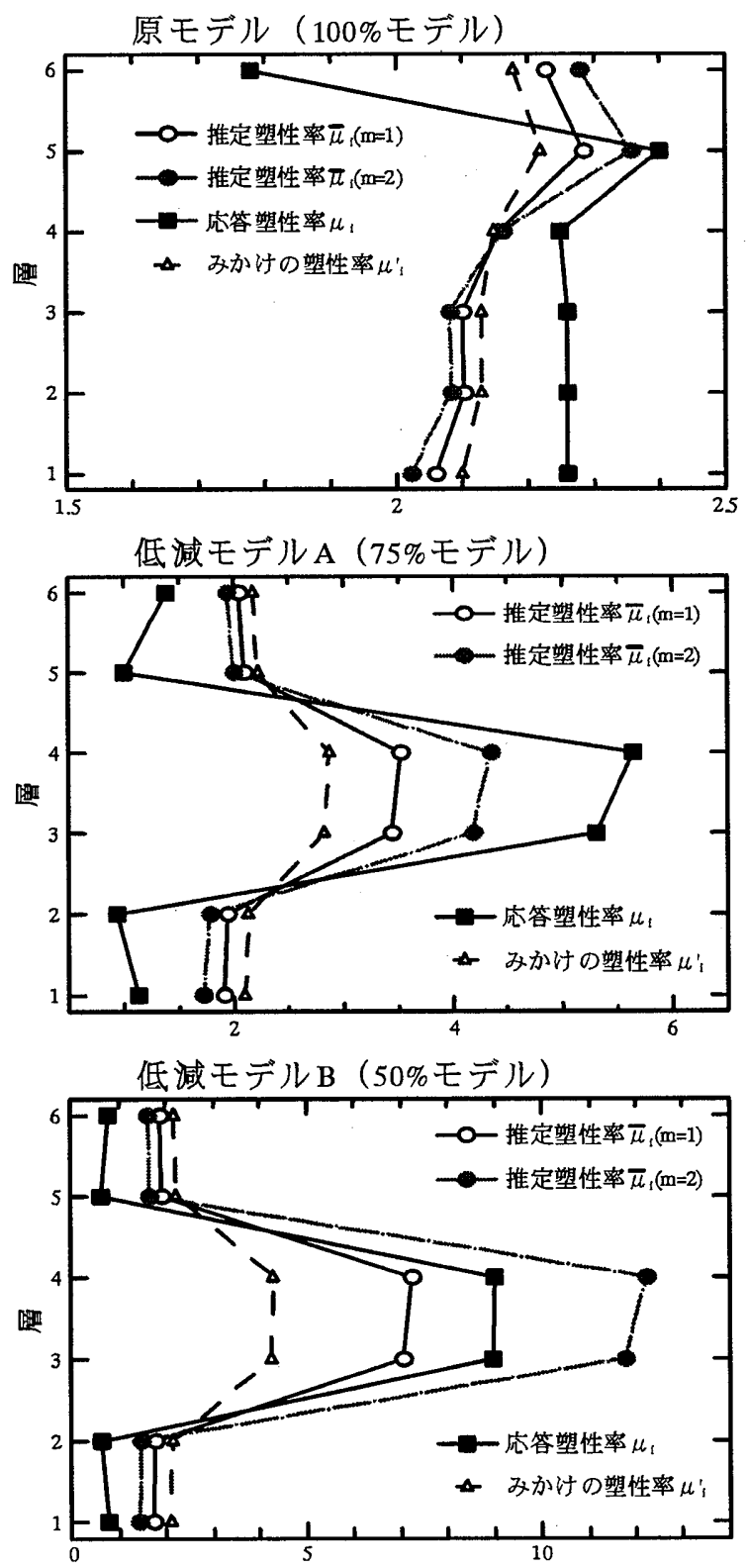

図 2 各モデルの推定塑性率 $\bar{\mu}_{i}$
を求めた。弾塑性モード解析は, 各階の弹塑性応答波形から共分散 マトリクスを作成し，これを直交化することにより，近似的な弾塑 性モードと時刻関数の積の総和で, 応答を表現する方法である（文 献 [3], 文献 [4]参照）。また, 推定1次モードの最上層の值 ${ }_{1} v_{6}$ が, 最上層層間変位和 $D_{6}$ と一致するような 1 次の分布 $V_{i}^{\prime}$ を 求めた。

$$
\begin{aligned}
\{y(t)\} & =\left\{{ }_{1} v\right\}_{1} a(t)+\left\{_{2} v\right\}_{2} a(t)+\cdots+\left\{_{n} v\right\}_{n} a(t) \\
& =\sum_{s=1}^{n}\left\{{ }_{s} v\right\}_{s} a(t) \\
& =[V]\left\{_{s} a(t)\right\}
\end{aligned}
$$

${ }_{s} a(t) ； \mathrm{~s}$ 次の時刻 $\mathrm{t}$ における推定モード振幅

$\left\{{ }_{s} v\right\} ; \mathrm{s}$ 次の推定モードベクトル（\{s $\left.\left.v\right\}^{T}[M\}_{s} v\right\}=1$ に正規化） $[V]$; 推定モードマトリクス $\left.\left.\left({ }_{s} v\right\}^{T}[M]\right\}_{s} v\right\}=1$ に正規化 $)$ $\{y(t)\}$; 弹塑性地震応答記録（基整からの相対変位応答值） $[M]$; 質量マトリクス（対角）

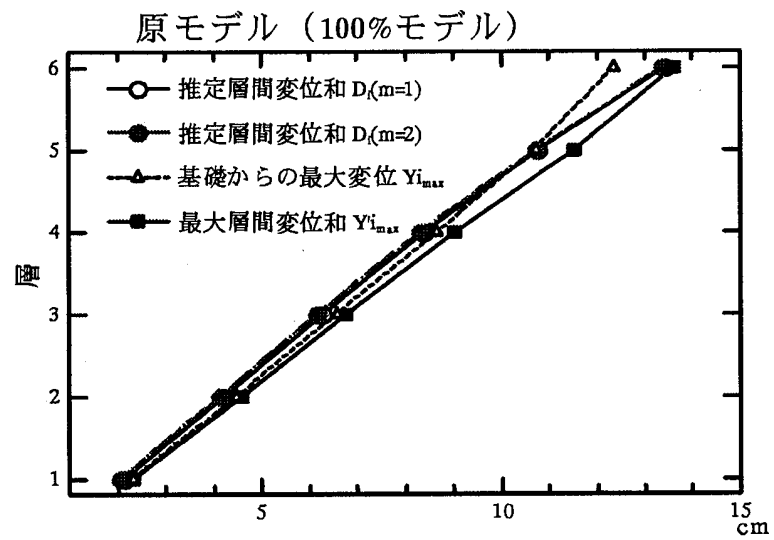

低減モデルA（75\%モデル）

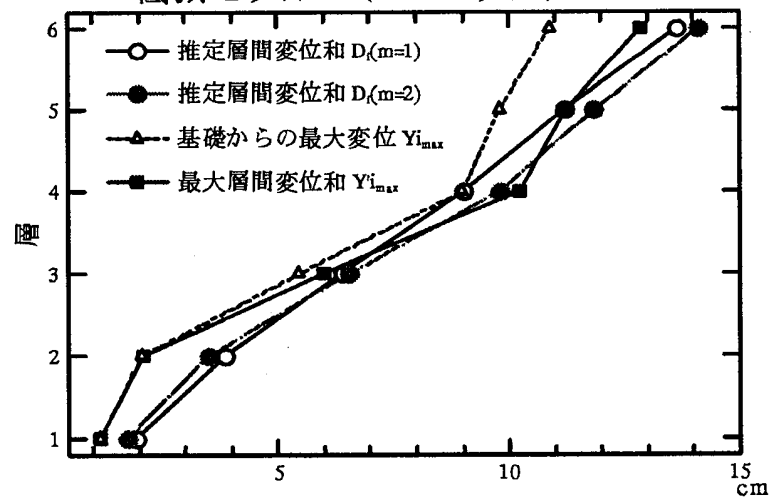

低减モデルB（50\%モデル）

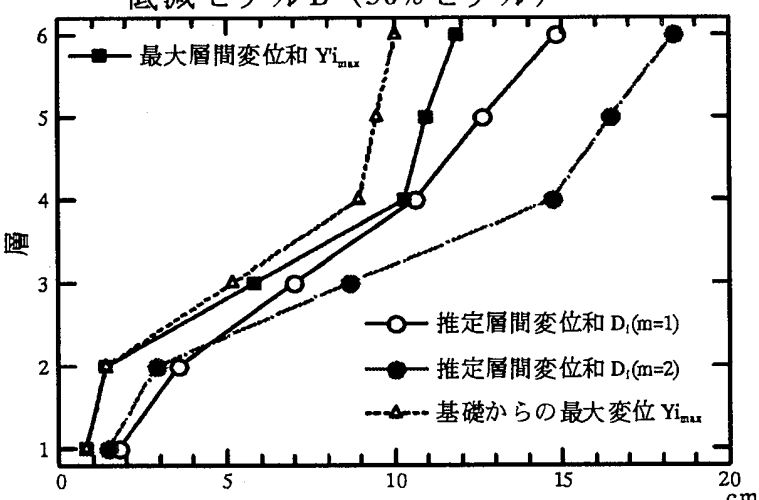

図 3 各モデルの推定層間变位和 $\mathrm{Di}$, 基琁からの最大 変位 $Y_{i \max }$, 最大層間変位和 $Y_{i \max }^{\prime}$ 
表 4 各モデルの推定 1 次モード $V_{i}^{\prime}$ と最大層間変位和 $Y^{\prime}{ }_{\text {imax }}$

\begin{tabular}{|c|c|c|c|c|c|c|}
\hline \multirow[b]{2}{*}{ i層 } & \multicolumn{2}{|c|}{$\begin{array}{c}\text { 原モデル } \\
(100 \% モ テ ゙ ル)\end{array}$} & \multicolumn{2}{|c|}{$\begin{array}{l}\text { 低減モデルA } \\
(75 \% \text { モテル) }\end{array}$} & \multicolumn{2}{|c|}{$\begin{array}{l}\text { 低隇モデルB } \\
\text { (50\%モデル) }\end{array}$} \\
\hline & $\begin{array}{c}\text { 推定1次 } \\
\text { モ一ド } \\
{ }_{1} V^{\prime} i\end{array}$ & $\begin{array}{c}\text { 最大層間 } \\
\text { 変位和 } \\
Y^{\prime} \text { imax }\end{array}$ & $\begin{array}{c}\text { 推定1次 } \\
\text { モ一ド } \\
{ }_{1} V^{\prime} i\end{array}$ & $\begin{array}{c}\text { 最大層間 } \\
\text { 変位和 } \\
Y^{\prime} \text { imax }\end{array}$ & $\begin{array}{c}\text { 推定1次 } \\
\text { モ一ド } \\
{ }_{1} \mathrm{~V}^{\prime} \mathbf{i}\end{array}$ & $\begin{array}{c}\text { 最大層間 } \\
\text { 変位和 } \\
Y^{\prime} \text { imax }\end{array}$ \\
\hline$\overline{\overline{6}}$ & 13.62 & 13.62 & 12.87 & 12.87 & 11.88 & 111.88 \\
\hline 5 & 11.70 & 11.52 & 11.52 & 11.24 & 11.21 & 10.95 \\
\hline 4 & 9.28 & 9.02 & 10.39 & 10.21 & 10.57 & 10.31 \\
\hline 3 & 6.97 & 6.78 & 6.10 & 6.00 & 5.97 & 5.83 \\
\hline 2 & 4.65 & 4.56 & 2.16 & 2.09 & 1.20 & 1.41 \\
\hline 1 & 2.35 & 2.31 & 1.11 & 1.16 & 0.60 & 0.79 \\
\hline
\end{tabular}

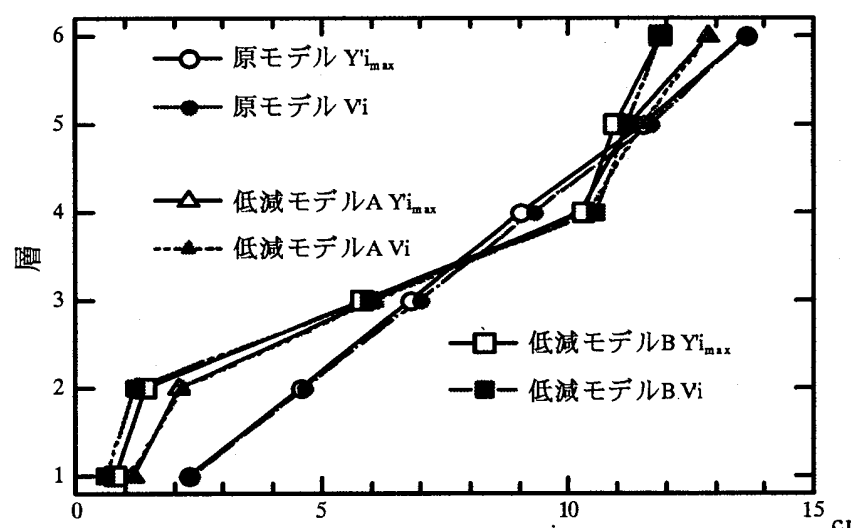

図 4 各モデルの推定 1 次モード形 $V_{1}{ }_{i}^{\prime}$ と最大層間変位和 $\mathrm{Yi}_{\max }$ との比較

頂部変位を一致させた推定 1 次モード $V_{i}{ }^{\prime}$ と最大層間変位 和 $Y_{i \max }^{\prime}$ を比較した。それらを表 4 , 図 4 に示した。両者は, かなり よく一致している。

\section{(2) 等価 1 次周期}

各モデルに対して，それぞれ 10 波の模擬地震動に対して，1 次 の推定モード振幅が最大となる近傍士 1 秒の 1 次の推定モード振 幅 $\{a(t)\}$ の波形を取り出し，この波形のスペクトル解析を行った。 各モデルごとに, 10 波に対するスペクトルの平均值を図 5 に示した。 各モデルともスペクトルのピークがはっきり現れ，また，原モデル， 低減モデル A（75\%モデル），低減モデルB（50\%モデル）となるに 従って,つまり中間層の耐力が落ちるほど, ピークの周期が長くな ってきている。これら 3 つのスペクトルのピーク值を表 5 の等価線 形化周期 $\left.T_{e}{ }^{2}{ }^{2}{ }^{3}\right)$ と比較した。ここで, 各モデルの等価線形化周期 $T_{e}$ は, 各地震波に対する各層塑性率の建物全体としての平均 $\bar{\mu}$ と降 伏時周期 $T_{y}$ より, 以下の式で定義した。

$$
\begin{aligned}
& T_{e A}=\sqrt{\bar{\mu}} \times T_{y} \quad \cdots[8] \quad \text { [等価線形化周期 } T_{e A} \text { ] } \\
& T_{e B}=\sqrt{0.7 \bar{\mu}} \times T_{y} \quad \cdots[9] \quad \text { [等価線形化周期 } T_{e B} \text { ] }
\end{aligned}
$$

いずれのモデルともスペクトルのピーク值は,等価線形化周期 $T_{e A}$, $T_{e B}$ の間の値となっている。

なお，本解析のような塑性率の差が大きいモデルに対して［8］，

[9] 式の妥当性に関しては, 今後検討をしていきたい。
表 5 初期周期, 降伏時周期及び各モテルの等価線形化周期と

\begin{tabular}{|c|c|c|c|}
\hline & & 1次 & \multirow{3}{*}{$\begin{array}{l}\text { 推定モ一ド } \\
\text { 振幅 (1次) } \\
\text { のスペクト } \\
\text { ルのピーク }\end{array}$} \\
\hline \multicolumn{2}{|c|}{ 初期周期(弾性剛性周期;Tc) } & 0.33 & \\
\hline \multicolumn{2}{|c|}{ 降伏時周期; Ty } & 0.60 & \\
\hline \multirow{2}{*}{ 原モデル } & TeA & 0.89 & \multirow{2}{*}{0.80} \\
\hline & TeB & 0.75 & \\
\hline \multirow{2}{*}{ 低減モデルA } & TeA & 0.96 & \multirow{2}{*}{0.84} \\
\hline & Тев & 0.80 & \\
\hline \multirow{2}{*}{ 低減モデルB } & $T_{e A}$ & 1.12 & \multirow{2}{*}{0.91} \\
\hline & Teв & 0.93 & \\
\hline
\end{tabular}
推定モード振幅のスペクトルのピーク（秒）

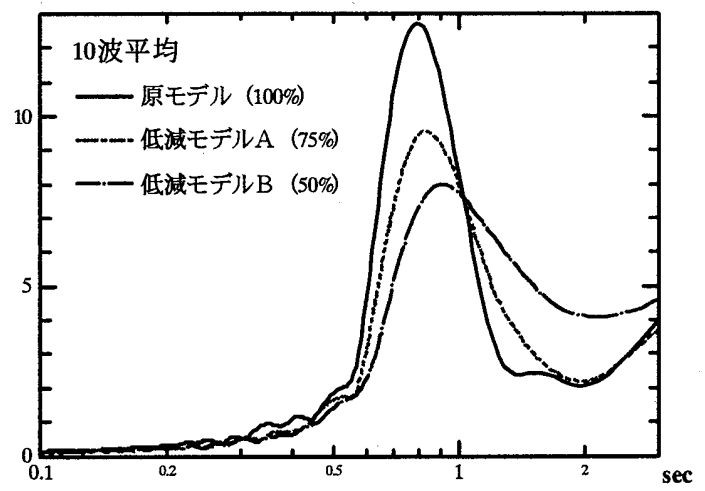

図 5 各モデルの 1 次の推定モード振幅

4.まとめ

偏差係数法による塑性率の推定方法を，層塑性率が中間層で大き くなる中間層崩壊建物モデルの解析例に適用した。10波の地震応答 記録により弾塑性応答計算で求めた塑性率と推定塑性率との比較, さらに応答計算で求めた応答変位, 最大層間変位和と推定層間変位 和との比較を行った。その結果, 偏差係数法による推定值がそれぞ れの応答值の傾向をよく表していた。また, 弾塑性モード解析を行 い, 推定 1 次モード形と実際の応答計算による変位を比較した。さ らにモデルごとに推定 1 次モード振幅のスペクトルのピークと等価 線形化周期を比較した。

今後は, これらの方法を, 周期の異なるモテルや, 塑性率の集中 場所が上層や下層の場合にも適用し，検討を加えていきたい。

\section{参考文献}

1）阪神淡路大震災調查報告「建䈎 1 鉄筋コンクリート構造」 pp.102-105

2) 益野英昌, 柴田明德“弾望性モード解析を用いた地震による建物の中 間首崩罗現象の検討” 日本建築学会大会(東海), pp.409-410, 2003.9. “同 (その 2$) ”$ 日本建筑学会大会 (北海道), pp.965-966, 2004.9.

3）益野英昌，柴田明徳 “多質点采の伦答記録に基づく弾望性モード特 性”，日本建築学会技術報告集第 15 号，pp.89-92，2002.6

4）益野英昌, 柴田明徳「モード分解に基づくペントハウスを有する建 物の地震応答性状の検討」，構造工学諭文集 Vol. 45B, pp.65·72, 1999.3

5）益野英昌，柴田明徳 “多質点系の応答記録に基づく弾塑性モード解析 （その 3) ”，日本建築学会大会 (北陸), pp.335-336, 2002.8

6 ）柴田明徳「地震による高層建物の撓み量」, 日本建築学会大会学術講 演梗概集号外，昭和 40 年 9 月, pp.133.

7）柴田明徳「最新耐震構造解析」，森北出版

8）益野英昌, 柴田明徳, 小川淳二, 㗪谷純一「R C 造震害建物の応答解 析に基づく付加構造物の制震効果の検討」，構造工学論文集V $V_{0}$ l. 44B, pp.295·300, 1998. 3

[2005年10月 18日原稿受理２006年 2 月20日採用決定］ 